\title{
Is dynamic general equilibrium a theory of everything?
}

\begin{abstract}
Should we interpret the contributions of Edward C. Prescott and his collaborators, especially Finn Kydland and Rajnish Mehra, to dynamic general equilibrium as just a mathematical restatement of pre-Keynesian business cycle theory in the language of Arrow and Debreu? This essay advances the contrary view that Prescott has been laying the foundations for a theory of everything in macroeconomics that will stretch well beyond the frictionless environments treated in its early version. A theory of everything is an attempt to explain key empirical observations in nearly every subfiel of macroeconomics from a simple, logically coherent conceptual platform with a minimum of institutional detail. After reviewing the current state of Prescott's agenda, we examine several examples of dynamic equilibrium in economies with constant returns to scale, complete markets, idiosyncratic productivity shocks, and limited capital mobility. These examples suggest that the Solow residual controls the entire path of aggregate output if redefine more broadly to include financial distributional and institutional variables; that the discount factor used in pricing streams of income will shift autonomously over time in response to endogenous changes in the set of unconstrained asset traders; and that a dynamic general equilibrium model with substantive frictions in
\end{abstract}

Prepared for the Special Issue of Economic Theory honoring Edward Prescott. We are indebted to Gaetano Antinolfi Athanasios Bolmatis, Jim Bullard and Bryan Ellickson for many discussions on these issues, to Lee Ohanian for bibliographic suggestions, to Robert Solow and two anonymous referees for comments. Some of the material was presented in a lecture series at the Arne Ryde Foundation, University of Lund, and at Brown University.

C. Azariadis

Washington University-St. Louis, 63130-4899 St. Louis, MO, USA

E-mail: azariadi@wustl.edu

L. Kaas $(\varangle)$

University of Konstanz, Box D145, 78457 Konstanz, Germany

E-mail: leo.kaas@uni-Konstanz.de 
financia markets goes some distance towards a joint account of well-known empirical anomalies in growth, business cycles, and asset returns.

Keywords Dynamic general equilibrium · Limited capital mobility

\section{JEL Classificatio Numbers B22 - D50 - E32 · G12}

\section{Introduction}

A dynamic general equilibrium (DGE) model is a parsimonious description of a private ownership economy as a stochastic dynamical system in a small space of physical goods and agent characteristics. Parsimony means that institutional details and exogeneity assumptions in the model should be as few in number and as simple in structure as the goals of the model allow. Combining first-orde conditions for all agents with clearing in all markets, a DGE model reduces economic behavior to a few stochastic differential or difference equations which defin the economy's laws of motion, much as Newton's equations characterize the motion of all macroscopic objects in a physical environment without frictions.

Economic laws of motion predict the time paths of aggregate variables in the short, medium and long runs. Those aggregates may include income and wealth, consumption and investment, wages and employment, physical capital and human skills, asset returns and financia variables, money and public debt, inflatio and exchange rates, and other objects of interest.

As a matter of scientifi principle, a "correctly" specifie DGE model amounts to a theory of everything that seeks to achieve for modern macroeconomics goals similar to those string theory has set for modern physics. Pushing the analogy with string theory a bit further, one may interpret DGE as an attempt to devise a unifie theoretical platform meant to explain a list of key empirical regularities or "big facts" in economic growth, asset returns, and business cycles. Since economics is a social science, one may add to this wish list two additional desiderata: successful econometric prediction and reliable policy evaluation.

Mehra and Prescott (1988) seem to have a similar list in mind when they comment on attempts to solve the equity premium puzzle by introducing habit formation or dropping expected utility:

"For such efforts to be successful, though, they must convince the profession that the proposed alternative preference structure is more useful than the now-standard one for organizing and interpreting not only these observations on average asset returns, but also other observations in growth theory, business cycle theory, labor market behavior, and so on. Anyone accomplishing that would have contributed significantl to economic science."

Skeptics will undoubtedly remark that no single macroeconomic model currently at hand delivers anything approaching the wish list outlined above. And those familiar with physics may fin presumption in the view that economics should embark, with some hope of success, on an endeavor similar to one that has frustrated the best minds in physics since Einstein. ${ }^{1}$ Does it not seem utopian to expect, even

${ }^{1}$ Seventy years after Einstein's f rst attempt to bring together relativity theory and quantum mechanics, string theory is still unable to deal with gravitation. See Susskind (2005) for an elementary exposition of string theory. 
far into the future, a unifie theory to emerge in a fiel that uses as many mutually incompatible languages as macroeconomics apparently does? As of this writing, we study unemployment in the search-theoretic language of Mortensen and Pissarides, monetary policy in the dynamic IS-LM language of Woodford, asset prices with the help of CAPM but also in the incomplete markets language of Constantinides and Duffie growth in the neoclassical language of Solow, and business cycles in several distinct tongues.

This essay advances the contrary view that the foundations for a theory of everything in macroeconomics are already at hand. They have been laid by Edward Prescott and his collaborators Finn Kydland and Rajnish Mehra in two seminal papers on real business cycles (1982) and asset returns (1985). These papers complete a body of work started by Solow (1956), Cass (1965) and Koopmans (1965), Brock and Mirman (1972) Lucas (1972, 1978), and Breeden (1979). With the help of several examples, we will argue that these foundations are much sturdier than the strict neoclassical conclusions which we associate with real business cycle theory, and with earlier generations of classical economists like Pigou (1929) and Hayek (1932). Real business cycle theory is viewed in this essay as considerably more than a dynamic restatement of pre-Keynesian economics in environments guided by Adam Smith's proverbial invisible hand.

Quite to the contrary, we intend to demonstrate by example that Prescott's ideas are well suited for, and easily extended to, economies with consequential market frictions and substantive heterogeneity. When frictions are large, real business cycle theory leaves room for inefficien y, indeterminacy, and meaningful stabilization policy. Amended in this way, dynamic general equilibrium comes closer to explaining some of the "big facts" that still puzzle macroeconomics.

Here is the plan for the remainder of this essay. Section 2 lists some of the key empirical observations that any unifie theory must explain; identifie those that still elude standard DGE models; and discusses several types of departures from that standard which claim to deal satisfactorily with some of the empirical anomalies. One of these departures, endogenous limitations on arbitrage and capital mobility, seems to hold particular promise both as a compelling description of financia constraints and as a relatively straightforward conceptual extension of the standard real business cycle model. Section 3 provides a non-technical overview of this extension, and outlines the results we should expect from it. Sections 4 through 7 present a number of examples dealing with growth, business cycles, the Solow residual, and financia markets. Section 8 concludes with some guesses about the explanatory power of DGE models with limited capital mobility.

\section{Is DGE empirically relevant?}

\subsection{A list of key facts}

Science expects theories to be both conceptually coherent and consistent with the facts, that is, with a list of salient empirical observations or reliable experimental findings Dynamic general equilibrium has had more success with the firs requirement than with the second one, and that explains in part why it appeals more to theoretically minded macroeconomists than to colleagues of an applied or policy bent. Exactly what menu of "salient" empirical regularities or big facts should 
we use to gauge the explanatory power of DGE? Borrowing from the Mehra and Prescott (1988) list, we will emphasize basic facts in growth, financia markets and business cycles. Here is a preliminary, and rather short, catalog: ${ }^{2}$

1. Growth and business cycles: Trends and fluctuation in the growth rates of per capita GDP, total factor productivity and potential GDP, physical and human capital, wealth and aggregate consumption, and employment, in individual nations and regional groups. The world distribution of income. Growth miracles and disasters. Deep recessions and depressions. Dynamic responses of GDP and other aggregates to money, productivity and other shocks.

2. Asset returns and financial markets: Average values and variations in the rates of return on broadly diversifie portfolios of private equity and public debt. Stock market volatility and bubbles. The distribution of financia wealth among households, and over domestic and foreign assets. Limited participation in financia markets.

Dynamic general equilibrium explains some of these facts in a satisfactory manner. For example, a standard neoclassical growth model will predict that relatively poor nations will experience sustained bursts of rapid, above-trend growth like those that occurred after 1950 in Finland, Ireland, Spain, Japan, and Singapore, as well as the ones unfolding in parts of Eastern Europe, China and India right now. Furthermore, a large chunk of postwar business cycles in developed nations is consistent with modest variations in total factor productivity. But many, perhaps most, of the facts in the catalog laid out above are still beyond the reach of the best DGE models available to us. We call these facts puzzles or anomalies.

We start with growth anomalies. One of them is the overwhelming importance of exogenous variations in total factor productivity which account for $60-90 \%$ of international differentials in the standard of living and in its rate of growth. ${ }^{3}$ Another is that growth does not look ergodic: the living standards in many poor countries are not catching up with the world average. In particular, convergence fails impressively in Latin America and Sub-Saharan Africa where unweighted per capita income lost ground relative to the world average in the second half of the twentieth century. Why have these countries not had, up to now at least, sustained bursts of rapid growth like other developing nations? A third growth anomaly is persistent international differences in growth rates of aggregate consumption for rich nations with diversifie and open financia markets. In the second half of the twentieth century Japanese consumption per capita grew faster than the world average: about twice as fast as the US and nine times as fast as Switzerland. Swiss and Japanese consumption seem to reflec domestic income, not world income as predicted by a DGE model with perfect capital mobility and identically homothetic utility functions.

An important business cycle puzzle is that emerging economies smooth their production and consumption less than rich countries. The growth rate of output and aggregate consumption in emerging economies like Argentina and Turkey deviates

${ }^{2}$ Quantitative summaries of growth facts appear in Ramey and Ramey (1995) and Azariadis (2005); of business cycle facts in Stock and Watson (1999), Christiano et al. (1999), King and Rebelo (1999), Cogley and Nason (1995), and Azariadis et al. (2004); and of financia facts in Diaz-Jimenez et al. (2002), Campbell (2003), and the Investment Company Institute (2004).

${ }^{3}$ See Klenow and Rodriguez-Clare (1997), and Prescott (1998). 
from trend twice as far as that of developed countries. On rare occasions, even rich countries go through deep or long lasting recessions like the US in the 1930s and Japan in the 1990s. Can factor productivity fall that much? If so, is it because technology collapses or because the market loses its ability to allocate resources to their best uses? Another puzzle concerns the dynamic response of GDP to productivity and interest-rate shocks. Those responses are not the monotone convergent paths predicted by standard DGE; they look more like irregular, hump-shaped waves. A third riddle is the pronounced fall in macroeconomic volatility, and the almost equally pronounced rise in microeconomic volatility since $1950 .{ }^{4}$

Financial markets bring to the table their own mysteries. The large equity premium, ${ }^{5}$ volatile equity prices, low returns on short-maturity public debt, and the identificatio of bubbles remain unfathomable questions that are unlikely to be resolved until we have better clues as to how markets discount streams of future income. How do we improve on the stochastic discount factor of standard DGE? In addition, we know that only $54 \%$ of US households trade in financia markets, directly or indirectly, and mostly in domestic securities. How does the remaining $46 \%$ smooth their consumption? Why do most investors avoid foreign assets?

To make matters even more challenging, the distribution of wealth relative to income is disproportionately skewed toward wealthier persons and the selfemployed. The richest 5\% of wealth holders own more than half of all financia wealth in the United States. Their median wealth-to-income ratio is more than twice as high as that of all other citizens even though their median age is identical. Why do the rich have higher saving rates?

\subsection{One theory for all facts?}

Can macroeconomics build a DGE model, or a closely related family of models, on the foundations laid by Prescott to answer convincingly all the questions asked above? What is the simplest model, assuming one exists, that will get this job done? The job will be "done" when we replace some of the spare institutional assumptions (perfect competition, perfect foresight or rational expectations, absolute property rights and perfect markets) of standard DGE with something messier, that is, with one or more frictions; figur out the predictions of the more complicated model; and fin that they are consistent with big facts. This is a tall order because we do not know exactly what assumptions lead to what predictions. We'll likely need time, much trial and more error to get anywhere. That may be too high a price to pay

\footnotetext{
${ }^{4}$ From a rolling sample of quarterly data, Blanchard and Simon (2001) calculate the standard deviation of US GDP growth in 2000 to be about $40 \%$ of its value in the 1950 s. Comin and Mulani (2004) fin the average standard deviation in the growth rate of real fina sales by individual $\mathrm{f} \mathrm{rms}$ to have doubled over the same period. Similarly, Campbell et al. (2001) estimate that the standard deviation of stock returns on individual $\mathrm{f} \mathrm{rms} \mathrm{has} \mathrm{went} \mathrm{up} \mathrm{by} 70 \%$ from 1962 to 1997 without any appreciable change in the volatility of market returns.

${ }^{5}$ McGrattan and Prescott $(2003,2005)$ point out that the standard definitio of the equity premium reflect many factors in addition to uninsurable aggregate risk. Examples are liquidity services from short-term Treasury bills, returns on unmeasured intangible corporate capital, changes in the tax treatment of earnings, of dividends and of individual retirement accounts. When these factors are removed, the average return on US equity since 1960 is only $1 \%$ more than the average return on high-grade, and highly procyclical, long-term bonds.
} 
for colleagues engaged in evaluating current monetary policy or predicting nearterm economic performance. DGE is unlikely to help them much until the next crop of models, embedding some frictions, is up and running. Until then, applied macroeconomists will have to work outside the DGE paradigm.

Those working inside the DGE paradigm face strict limitations on what they can assume about their economic environment. Exogenous objects are limited to preferences, endowments, technologies, initial wealth and its distribution, plus some public policies. ${ }^{6}$ Institutional and other exogenous distortions (adjustment and transaction costs, quality of governance and corruption, completeness of markets) are to be kept at a minimum and cannot be assumed to change over time or across countries, except as a by-product of deliberate action by households and firms Thus we are not allowed to blame rampant corruption for the low standard of living in the least developed nations because we take the quality of governance to be a joint product of low development, not a root cause of it. By the same token, one utility function should underlie all choices of a household, both real and financial For example, extreme aversion to risk is consistent with a high equity premium but also with backward-bending labor supply and saving schedules because risk aversion limits severely the substitutability between current consumption or leisure and their future values.

What we are free to bring to the paradigm are macroeconomic frictions of various types, that is, deviations from the strict Arrow-Debreu assumptions of the original DGE framework. Frictions drive a wedge between equilibria and optima. They have been at the forefront of research since Bewley (1986), and by now add up to a vast literature. ${ }^{7}$ Here are some of the more important frictions, together with their economic motivations, listed roughly in inverse order of how well they seem to fi into DGE:

1. Exogenous price and wage rigidities that intend to emphasize the non-neutrality of money.

2. Exogenous constraints on trading and market formation. Examples are liquidity and borrowing constraints that lead to buffer stocks of assets; collateral restrictions on borrowers which raise the volatility of investment decisions; missing markets and uninsurable idiosyncratic risks that raise the market price of aggregate risk; and restrictions on trading frequencies that influenc market participation.

3. Increasing returns to scale, set-up costs and other non-convexities which justify co-ordination failures, inefficien or multiple equilibria, financia autarky or investment cascades.

4. Strategic behavior, especially from policymakers, typically resulting in co-ordination failures.

6 Treating public policy as a collective outcome of rational individual action motivates a large political economy literature. Persson and Tabellini (2000) give an excellent survey of voting models for public policy.

${ }^{7}$ An all-too-brief list of interesting contributions would include the books by Evans and Honkapohja (2001) and Woodford (2003), the survey by Gali (2003) plus a number of original papers. Among those are Calvo (1983) on item (1); Bewley (1986), Aiyagari (1994), Kiyotaki and Moore (1997), and Krusell and Smith (1998) on item (2); Benhabib and Farmer (1994) on item (3); Lucas and Stokey (1983) on item (4); Rotemberg (1982) on item (5); and Bullard (1994) on item (6). 
5. Monopolistic competition resulting in output gaps and price markups that vary over the business cycle.

6. Learning and bounded rationality which may cause excess volatility. And

7. Endogenous restrictions on trading and market formation, including constraints on debt, and limitations on capital mobility and arbitrage.

Reconciling (1) and (2) with DGE is problematic. The firs item makes direct assumptions about endogenous variables. The second one is even harder to deal with, despite the enormous literature on liquidity constraints and uninsurable personal risks, because it is incompatible with stationarity. ${ }^{8}$ Uninsurability means that agents must typically condition their decisions on the entire path of their income instead of just on current wealth, as in the standard DGE model. Describing with any generality economies with so large a state space seems beyond current mathematics, including numerical computation software.

Our own guess is that much progress can be made in DGE if we take friction (7) as seriously as suggested in applied work assessing the quantitative impact of credit markets on aggregate output. ${ }^{9}$ Accordingly, we propose to replace the assumption of perfect asset markets with another that limits the mobility of financial capital and leaves on the table unexploited arbitrage opportunities. Endogenous ceilings on debt and capital mobility, of the type pioneered in exchange economies by Eaton and Gersovitz (1981) and Kehoe and Levine (1993), seek to ensure solvency for all agents in all event histories. They are easy to squeeze into a DGE environment with complete, but imperfect, financia markets in which all securities can be priced, and all agents can obtain partial insurance against personal risk. As we hope to show later, macroeconomic models with these features display many of the properties that motivate the frictions outlined in items (1)-(6) above.

\section{Limited capital mobility in financia markets}

Consider a DGE environment with public information in which lenders or buyers of insurance have a limited capacity or legal right to enforce their claims on borrowers or sellers of insurance. Because all information is public, bankruptcy has no useful social function. It does not enrich the set of securities markets nor does it improve the opportunities to share risks among households. Think next of a disinterested auctioneer, with complete knowledge of all agent characteristics, who is assigned the job of clearing markets and forestalling bankruptcy by any individual at any point in time. A sensible way to achieve the second objective is by imposing short-sale constraints, that is, restrictions on how much each household or fir is allowed to borrow relative to their income or net assets, and on how much insurance each one can promise to sell in every conceivable turn of future events. These restrictions are called endogenous because they describe the highest debt-income

\footnotetext{
8 This point is made forcefully in Kehoe and Levine (2001).

${ }^{9}$ From a set of household panel data, Jeong and Townsend (2005) estimate that more than $70 \%$ of the growth in Thai TFP, from 1976 to 1996, is directly or indirectly due to improved household participation in credit markets. In simulations of a calibrated model with international capital mobility, Antunes et al. (2006) fin that stricter domestic enforcement of lenders' property rights accounts at least half the difference between US GDP per capita and that of several other nations (Brazil, France, Greece, Italy).
} 
or debt-equity ratio that a household or fir can reach without voluntarily choosing to default.

In these idealized environments, debt limits successfully deter all bankruptcies by balancing exactly the gains that accrue to each bankrupt household or fir (relief from part or all loan payments of principal and interest, or from insurance indemnities owed) with the corresponding penalties that the auctioneer is empowered to impose. These penalties include settling a fraction of the outstanding debt, and restricted access to future asset trading. Bankrupt borrowers thus surrender some or all gains from future participation in financia markets, and compromise their ability to smooth consumption or production in the future when their productivity fluctuates

One prediction from this framework is that bankruptcy will not tempt those who most need to smooth consumption or production: entrepreneurs, owners of capital, self-employed persons and others with large income fluctuations also cyclical businesses with large productivity gyrations. The auctioneer will assign households and firm in this group generous limits on debt and short sales. They will borrow a lot in bad times, carry large asset balances relative to income in good times, and trade actively in financia markets.

On the other side of the spectrum of personal characteristics will be households that do not value smooth consumption very much. People with stable incomes, low aversion to risk or high intertemporal substitutability in consumption will be assigned low debt limits relative to their income and will not be very active in asset markets. Some of these agents will be allowed no short sales whatever, and will stay completely out of asset markets, like many poorer households in the US.

Aside from personal characteristics, what other factors determine average debt limits in a given economy? How do households and firm behave in the aggregate? What are the big differences between frictional economies with debt limits and frictionless ones with perfect credit markets? Some answers are beginning to emerge in recent research, ${ }^{10}$ even though many details are yet to be worked out. In particular:

1. Default penalties, or gains from trading assets, are crucially important determinants of debt limits. Societies that strongly protect the property rights of lenders will also enjoy higher debt-to-income limits and more developed financia markets than societies that tolerate default.

2. Short-sales constraints slow down capital mobility. Loans, insurance and other forms of financia capital will not necessarily, or even typically, fl w to credit rationed agents who value them the most. Some loans will go, for example, to less productive firm (say, older ones with large equity positions) that are still within their debt limits.

3. Economies with financia market frictions misallocate capital and produce less income than their technology and stocks of inputs permit. Consequently,

4. Total factor productivity, as reckoned conventionally by the Solow residual, understates the technology frontier of every economy, especially that of less developed nations with weak property rights as define in (1). Measured productivity is contaminated by the limited ability of financia markets to re-direct resources to the most efficien firm or sectors.

10 See, for example, Alvarez and Jermann (2000), Azariadis and Kaas (2004, 2005, 2007). 
5. Weak property rights for lenders, of the type we observe in many emerging economies, imply weak financia markets with insufficien lending and inadequate smoothing of production. The outcome is slow growth with large fluctuation about trend, especially when firm and sectors undergo large changes in relative productivities.

6. Because debt limits weaken the ability of households and firm to smooth consumption and production by trading assets, we should expect debt-constrained economies to display greater volatility in output, consumption and asset prices than we are accustomed to expect in economies with perfect markets. An economy with perfect markets behaves in a highly predictable manner: a unique law of motion typically guides its path from any initial state to a socially desirable steady state. The economy with debt limits turns out to be much more volatile, and often less predictable, too.

7. When default penalties are small or short lived, the outcome can be stringent debt limits and several steady states (a bad state, and a better one), with distinct laws of motion leading to each steady state or even to a limit cycle. Dynamic behavior is indeterminate because of powerful dynamic complementarities in consumption or production which open the door for multiple equilibria. This problem occurs because debt limits greatly reduce the substitutability of consumption goods over time to the point where current consumption becomes a complement of future consumption. Debt constraints at different dates can also be strong complements, because a generous debt limit in the future raises the gains from trading in financia markets, lifts the cost of default today and correspondingly raises today's debt limit.

8. When default penalties are large or last long, complementarities weaken and equilibrium may be unique-but it is still more volatile than it would be if financia markets were perfect. For example, asset returns would fluctuat in an endowment economy with heterogeneous agents and fixed total income. Equilibrium asset returns here depend on the consumption plans of unconstrained households only. Even though total income remains constant, the size and income of the credit-unrationed group changes over time, and so do asset returns.

\section{Growth and fluctuation with no mobility}

\subsection{Setting}

Following Azariadis and Kaas (2004), we study equilibria in an economy that produces a single consumption good from physical capital alone, using a variety of idiosyncratic, constant-returns-to-scale technologies. Idiosyncratic productivity changes require this economy to reallocate its capital stock every period to the most efficien producers. Reallocating capital takes place in a loan market that converts the savings of households and producers, especially those with low capital productivity, into loans for owners of highly productive technologies.

To prevent default, the auctioneer calculates and imposes on each producer a debt limit that define a maximal debt-equity ratio for each period. Binding debt limits stanch the $\mathrm{fl} \mathrm{w}$ of capital from low-productivity technologies to high ones, and keep the economy from producing as much as its aggregate capital stock would permit if financia markets were perfect. 
Time is discrete, $t=0,1, \ldots$, and there is no uncertainty of any kind. The production possibilities frontier is described by a an exogenous sequence ${ }^{11}$ of deterministic aggregate states $\left(A_{t}\right)_{t=0}^{\infty}$ with history

$$
A^{t}=\left(A_{0}, A_{1}, \ldots, A_{t}\right)
$$

There are $N+1$ infinitely-l ved producer-consumers indexed $i=0,1, \ldots, N$, endowed with initial capital $k_{0}(i)$, a common utility function $\sum_{t=0}^{\infty} \beta^{t} \log \left[c_{t}(i)\right]$ define over consumption sequences, and proprietary technologies of the form

$$
y_{t}(i)=A_{t}(i) k_{t}(i)=z_{t}(i) A_{t} k_{t}(i),
$$

where

$$
\begin{aligned}
z_{t}(i) & =z(i) \quad \text { if } t=0,2, \ldots \\
& =\frac{\alpha}{z(i)} \quad \text { if } t=1,3, \ldots
\end{aligned}
$$

In this equation, $y_{t}(i)$, the output by agent $i$, includes undepreciated capital; $k_{t}(i)$ is capital used by $i$ in period $\mathrm{t}$ and installed in period $\mathrm{t}-1$ (that is, the sum of equity plus debt); and $z_{t}(i)$ is an idiosyncratic, periodic shock to productivity ${ }^{12}$ which lies in the interval $[\alpha, 1]$, with $0 \leq \alpha \leq 1$. The function $z(i)$ is decreasing in $i$ with $z(0)=1$ and $z(N)=\alpha$. One example is

$$
z(i)=1-\frac{1-\alpha}{N} i, \quad i=0, \ldots, N
$$

All agents have the same average factor productivity; however the most efficien producer is $i=0$ in even periods, and $i=N$ in odd ones. Efficien technologies lie on the PPF with factor productivity $A_{t}$. There is no stock market distinct from the loan market. Shares in non-proprietary technologies are equivalent to direct loans.

No human capital exists in this economy. Households own at the outset the present value of all future returns to capital, and therefore need not borrow against future income in order to pay for current consumption; but they may need loans to take advantage of unusually high idiosyncratic productivity shocks.

An informal definitio of competitive equilibrium is the following: each agent $i=0, \ldots, N$ maximizes over sequences of consumption, equity and debt, taking as given the sequences $\left(R_{t}, \theta_{t}(i)\right)_{t=0}^{\infty}$, that is, the yield on loans of capital, and the maximal debt-to-equity ratio imposed by the auctioneer. In addition, the loan market clears; and the debt limit $\theta_{t}(i)$ is the largest one that, at each period $t$, keeps the continuation utility of solvency from falling below the continuation utility of

11 Since this sequence define the aggregate production possibilities of the economy, it should itself be regarded as the endogenous outcome of individual and public decisions to invest in scientifi know-how, research and product development. Endogenous technical change, investigated by Grossman and Helpman (1991), and Aghion and Howitt (1992) among others, is outside the scope of this introductory essay. One reason for this omission is that good financia markets are as likely to influenc the investments in knowledge as they do for physical capital and human skills.

12 In a stochastic environment, individual factor productivities can be thought of as deterministic but idiosyncratic functions of a Markovian aggregate state. This assumption eliminates uninsurable risk while preserving firm-specif shocks. 
default. This definitio is identical to the one familiar from standard DGE models, except in what concerns debt limits.

Agents with factor productivity below the cost of capital will lend out their entire stock of equity and obtain a gross return $R_{t}$. Those with productivity $A_{t}(i)>R_{t}$ will want to borrow an infinit amount, and will be prevented from doing so by their debt limits. Their rate of return on each unit of equity

$$
\tilde{R}_{t}(i)=A_{t}(i)+\theta_{t}(i)\left[A_{t}(i)-R_{t}\right]
$$

is the sum of a direct equity return plus a leveraged return from debt. For any agent $i$, the return on equity is therefore

$$
\tilde{R}_{t}(i)=R_{t}+\left[1+\theta_{t}(i)\right] \max \left[A_{t}(i)-R_{t}, 0\right] .
$$

Before we look more closely at equilibria with debt constraints, we review the two benchmark cases of perfect capital mobility and zero capital mobility, corresponding to debt limits being either very large or zero for all agents. In particular, perfect mobility corresponds to standard dynamic general equilibrium with unique, Pareto optimal outcomes and equality of actual to potential output. Fluctuations and growth are driven entirely by changes in the economy's production possibilities frontier, and the initial distribution of capital among producers has no influenc on aggregate outcomes.

At the opposite end, zero capital mobility refers to a financiall autarkic environment where output is below potential and the growth rate falls short of what is permitted by improvements in production possibilities. How far short will depend on the initial distribution of wealth; adverse initial distributions may drive the output gap all the way to $100 \%$ of production possibilities. Growth rates are generally lower and more volatile in this environment, and business cycles may occur even if production possibilities do not change.

\subsection{Perfect mobility}

All capital in this environment is used by the most efficien producer, that is, by $i=0$ in even-numbered periods and $i=N$ in odd periods. The yield on loans is

$R_{t}^{*}=A_{t}$ for each $t$. If $e_{t}(i)$ denotes equity holdings by agent $i$ at the start of period $t$, then individual decisions satisfy the familiar rules

$$
e_{t}^{*}(i)=\beta R_{t-1}^{*} e_{t-1}^{*}(i) \quad c_{t}^{*}(i)=(1-\beta) R_{t}^{*} e_{t}^{*}(i),
$$

and the initial condition

$$
e_{0}^{*}(i)=k_{0}(i) \text {. }
$$

Iterating equation (4) forward, we obtain the vector

$$
\left(e_{t}^{*}(i), c_{t}^{*}(i)\right)=\beta^{t} k_{0}(i)\left(1,(1-\beta) R_{t}^{*}\right) \prod_{s=0}^{t-1} R_{s}^{*} .
$$


Total equity equals the aggregate capital stock

$$
K_{t}^{*}=\beta^{t} K_{0} \prod_{s=0}^{t-1} A_{s}
$$

with $K_{0}$ given, and aggregate output is

$$
Y_{t}^{*}=A_{t} K_{t}^{*}=\beta^{t} K_{0} \prod_{s=0}^{t} A_{s} .
$$

This define the familiar output growth factor

$$
n_{t}^{*}=\frac{Y_{t+1}^{*}}{Y_{t}^{*}}=\beta A_{t+1} .
$$

It would be comforting to know that this ideal equilibrium can be implemented in an environment with debt constraints. Under what conditions are debt limits sufficientl generous to permit all capital to $\mathrm{fl}$ w to agents $i=0$ or $i=N$ ? The disappointing answer to this question is "almost never" or, more precisely, only if idiosyncratic productivity fluctuation are unrealistically large. To see that, we adopt temporarily the Kehoe-Levine (1993) approach which imposes the strongest possible penalty for default, perpetual exclusion from all future asset market trades, and therefore generates the biggest possible debt limits obtainable if we do not directly prohibit default.

Any agent $i=0$ or $N$ who borrows the entire capital stock, net of his own equity, at $t=T-1$ and considers default at $t=T$, will compare the continuation utility from solvency, $V_{T}^{*}$, against the continuation utility from autarky, $V_{T}^{a}$. These payoffs are define from

$$
\begin{aligned}
& V_{T}^{*}=\sum_{t=T}^{\infty} \beta^{t-T} \log \left[c_{t}^{*}(i)\right], \\
& V_{T}^{a}=\sum_{t=T}^{\infty} \beta^{t-T} \log \left[c_{t}^{a}(i)\right],
\end{aligned}
$$

where $c_{t}^{*}(i)$ is described by equation (6) with $R_{s}^{*}=A_{s}$, and $c_{t}^{a}(i)$ satisfie a similar expression with autarkic yields

$$
\begin{aligned}
R_{s}^{a}(i) & =A_{t} \quad \text { if } s=T, T+2, \ldots \\
& =\alpha A_{t} \quad \text { if } s=T+1, T+3, \ldots
\end{aligned}
$$

To implement the perfect mobility equilibrium under limited capital mobility, we need $V_{T}^{*} \geq V_{T}^{a}$ for all $T \geq 0$, that is,

$$
0 \leq \sum_{t=T}^{\infty} \beta^{t-T} \log \left[\frac{c_{t}^{*}(i)}{c_{t}^{a}(i)}\right]
$$




$$
\begin{aligned}
& =\sum_{t=T}^{\infty} \beta^{t-T}\left\{\log \left[\frac{k_{0}(i)}{K_{0}}\right]+\log \prod_{s=T}^{t}\left(\frac{A_{s}}{R_{s}^{a}}\right)\right\} \\
& =\frac{1}{1-\beta} \log \left[\frac{k_{0}(i)}{K_{0}}\right]-\frac{\beta \log \alpha}{(1-\beta)^{2}(1+\beta)}
\end{aligned}
$$

for each $i=0, N$. This inequality, equivalent to,

$$
\frac{k_{0}(i)}{K_{0}} \geq \alpha^{\beta /\left(1-\beta^{2}\right)}
$$

is hard to satisfy as it requires too low a value of $\alpha$, that is, very large fluctuation in idiosyncratic factor productivities. For example, if initial capital is distributed uniformly over $\mathrm{N}+1$ producers, then for $\beta=0.96$, inequality (10) requires $\alpha$ to be no more than 0.707 if $N=63$, not above $\frac{1}{2}$ if $N=4,195$, and zero as $N \rightarrow \infty$.

\subsection{No mobility}

Agents are financiall autarkic in this environment where debt-to-equity limits are zero for all agents at all times. Rates of return are the autarkic yields

$$
\begin{aligned}
R_{t}^{a}(i) & =z(i) A_{t} \\
& =\frac{\alpha A_{t}}{z(i)} \quad \text { if } t=0,2, \ldots \\
& \text { if } t=1,3, \ldots
\end{aligned}
$$

By analogy with Eq. (6) and (7b), autarkic capital stocks and outputs, for each agent $i$, are

$$
\begin{aligned}
& k_{t}^{a}(i)=\beta^{t} k_{0}(i) \prod_{s=0}^{t-1} R_{s}^{a}(i), \\
& y_{t}^{a}(i)=\beta^{t} k_{0}(i) \prod_{s=0}^{t} R_{s}^{a}(i) .
\end{aligned}
$$

Assuming a uniform initial distribution of capital, we compute aggregate output

$$
Y_{t}^{a}=\sum_{i=0}^{N} y_{t}^{a}(i)=\beta^{t}\left[K_{0} /(1+N)\right] \sum_{i=0}^{N}\left[\prod_{s=0}^{t} R_{s}^{a}(i)\right] .
$$

Next we compare Eqs. (7b) and (13) to obtain the following expressions connecting autarkic and perfect-mobility aggregates for all $m=0,1, \ldots$

$$
\begin{aligned}
& Y_{2 m}^{a}=\alpha^{m} Y_{2 m}^{*}, \\
& Y_{2 m+1}^{a}=\alpha^{m}(\alpha / \mu) Y_{2 m+1}^{*},
\end{aligned}
$$

where $\mu \in(\alpha, 1)$ is the harmonic mean of all $z(i)$, i.e., $\frac{1}{\mu}=\frac{1}{1+N} \sum_{i=0}^{N}[1 / z(i)]$. 
Equation (14) define capacity utilization variables which are ratios of actual output to potential output that can be produced from the initial capital stock, that is,

$$
\phi_{2 m}=\alpha^{m}, \quad \phi_{2 m+1}=(\alpha / \mu) \alpha^{m}, m=0,1, \ldots
$$

The complete absence of asset markets in this economy lays waste to its growth potential. Capacity utilization, as define in Eq. (15), goes to an asymptotic value of zero, while aggregate output may not be bounded away from zero. Autarkic growth rates $n_{t}^{a}$ are systematically below those of the standard DGE model:

$$
\begin{aligned}
& n_{2 m}^{a}=(\alpha / \mu) n_{2 m}^{*}, \\
& n_{2 m+1}^{a}=\mu n_{2 m+1}^{*} .
\end{aligned}
$$

\subsection{Do financia markets matter? A numerical example}

Suppose the production possibility frontier is constant at $A_{t}=A=1.02 / \beta$ for all $t$. That implies a steady $2 \%$ per period growth rate of output in the economy with perfect mobility. Suppose also that relative productivities range between 0.9 and 1 , and that $\mu=0.95$ is the harmonic mean of idiosyncratic productivities in even numbered periods. Then we obtain autarkic growth factors from Eq. (16), that is,

$$
\begin{aligned}
n_{t}^{a} & =0.9663 \text { if } t=2 m, \\
& =0.8712 \text { if } t=2 m+1 .
\end{aligned}
$$

Mean autarkic growth fluctuate by about $9.5 \%$ points between $-3.37 \%$ and $-12.88 \%$. The geometric average growth is nearly minus $8.25 \%$, that is, more than ten points below ideal. This gives us a rough upper bound of how important financia markets can be. ${ }^{13}$

\section{Growth and fluctuation with limited mobility}

\subsection{Preliminaries}

In this section we study environments define by an exogenous institutional parameter $m \in[0,1]$ that describes the property rights of lenders, that is, the fraction of the principal and interest owed that a bankrupt lender must pay to his creditors. In return for this concession, defaulters are allowed to lend freely in the future, and their assets are protected against former creditors. An additional penalty for bankruptcy is perpetual exclusion from borrowing.

Debt limits are indirectly controlled by the parameter $m$, that is, by the bankruptcy laws of each society. If $m=1$, we are back in the standard DGE environment of perfect capital mobility; property rights are strictly enforced, and debt limits are irrelevant. At the other extreme, $m=0$ will put us close to the sovereign default environment of Bulow and Rogoff (1989); debt limits are small because exclusion from future borrowing does not punish default strongly.

An economy with limited capital mobility consists of the following objects:

\footnotetext{
${ }^{13}$ Financial markets would be less important if labor came into play as a factor of production with greater mobility than capital.
} 
- An exogenous parameter $m \in[0,1]$ for property rights, exogenous sequences $\left(A_{t}\right)$ for aggregate productivity and relative productivity $\left(z_{t}\right)$, where $0 \leq z_{t} \leq 1$ for all $t$. Productivity is $A_{t}$ for efficien producers, $z_{t} A_{t}$ for inefficien ones.

- A pair of households $i=0,1$ with common logarithmic utility function and periodic technologies

$$
\begin{aligned}
& \left(y_{t}(0), y_{t}(1)\right)=A_{t}\left(k_{t}(0), z_{t} k_{t}(1)\right) \text { if } t=0,2, \ldots \\
& =A_{t}\left(z_{t} k_{t}(0), k_{t}(1)\right) \text { if } t=1,3, \ldots
\end{aligned}
$$

- A loan market run by an auctioneer who sets yields $\left(R_{t}\right)$ on loans and imposes debt limits $\left(\theta_{t}(m)\right)$ on borrowers.

- Initial conditions on capital stocks $\left(k_{0}(0), k_{0}(1)\right)$ all of which are assumed to be equity. There are no initial debts.

In each possible economy $\left(\left(A_{t}\right),\left(z_{t}\right), m, k_{0}(0), k_{0}(1)\right)$, we defin a dynamic general equilibrium in the usual way:

1. A sequence of normalized yields on loans, $\tilde{r}_{t}=\tilde{R}_{t} / A_{t}$, and on the equity of efficien producers

$$
\tilde{r}_{t}=\tilde{R}_{t} / A_{t}=1+\left(1-r_{t}\right) \theta_{t}(m)
$$

2. A sequence of maximal debt-equity ratios $\theta_{t}(m)$ on efficien producers restricting the amount of capital they employ, viz.,

$$
k_{t}(i)-e_{t}(i) \leq \theta_{t}(m) e_{t}(i) .
$$

Debt limits on inefficien producers are identically zero.

3. Given $\left(r_{t}, \theta_{t}(m)\right)$, each household chooses $\left(c_{t}(i), e_{t}(i), k_{t}(i)\right)$ to maximize discounted utility subject to the technologies in (17), the arbitrage condition (18a), the debt constraint in (18b) and the budget constraint

$$
c_{t}(i)+e_{t+1}(i)=A_{t} \tilde{r}_{t} e_{t}(i)
$$

if $i$ is a borrower, and

$$
c_{t}(i)+e_{t+1}(i)=A_{t} r_{t} e_{t}(i)
$$

if $i$ is a lender.

4. The loan market clears, and debt limits $\theta_{t}(m)$ are the highest values that will deter default at each $t$.

Note from Eq. (18a) that individual equity returns are the sum of an idiosyncratic marginal product of capital plus the excess of MPK over the cost of capital multiplied by the debt-equity ceiling. Thus $\tilde{r}_{t}=r_{t}$ if $\theta_{t}=0, \tilde{r}_{t}>r_{t}$ if $\theta_{t}>0$.

Consumption-saving decisions are straightforward, i.e.,

$$
\left(c_{t}(i), e_{t+1}(i)\right)=(1-\beta, \beta) A_{t} \tilde{r}_{t} e_{t}(i)
$$

if $i$ is an efficien producer, and

$$
\left(c_{t}(i), e_{t+1}(i)\right)=(1-\beta, \beta) A_{t} r_{t} e_{t}(i)
$$


if $i$ is inefficient These decisions are made consistent by loan market equilibrium which cannot exist unless the yield $R_{t}$ falls between the lowest and highest productivity, or

$$
z_{t} A_{t} \leq R_{t} \leq A_{t} .
$$

Let $i$ be the efficien producer at the time $t$ and $j \neq i$ be the inefficien one. Then the loan market clears if

$$
\begin{aligned}
\theta_{t}(m) e_{t}(i) & \leq e_{t}(j) \quad \text { if } r_{t}=z_{t}, \\
& =e_{t}(j) \quad \text { if } r_{t} \in\left(z_{t}, 1\right), \\
& \geq e_{t}(j) \quad \text { if } r_{t}=1 .
\end{aligned}
$$

These inequalities remind us that loan supply is indeterminate at $r_{t}=z_{t}$; loan demand is indeterminate at $r_{t}=1$. Next we describe how the auctioneer calculates debt limits for borrowers.

\subsection{Debt-equity limits}

The auctioneer seeks for each $m$ a sequence of debt-equity limits $\theta_{t}(m)$ that balance the cost and benefit of default for borrowers. Borrowers are efficien producers who tap the loan market every two periods to exploit the difference between their productivity and the generally lower cost of capital. Loan default shuts off these arbitrage gains but leaves borrowers with a higher initial wealth than would solvency.

Suppose $\theta_{t}(m)$ is the highest debt-equity ratio that will deter default by a borrower who starts period $t$ with one unit of equity and borrows the maximum allowed. If he remains solvent, then the wealth or resources available for consumption and saving at $t$ are the right-hand side of Eq. (19a), i.e., $w_{t}=A_{t} \tilde{r}_{t}$. If he defaults, he saves a fraction $(1-m)$ of the principal and interest due, raising wealth to $w_{t}^{b}(i)=A_{t}\left[\tilde{r}_{t}+(1-m) r_{t} \theta_{t}(m)\right]$.

Subsequent values of these wealth sequences are compounded at a yield $A_{t+1} r_{t+1}$ for period $t+1$ when agent $i$ is an inefficien producer who lends out his entire wealth; and at a yield $A_{t+2} \tilde{r}_{t+2}$ in period $t+2$ if agent $i$ is solvent, or $A_{t+2}$ if agent $i$ is in default and cannot borrow again. Thus we have wealth vectors

$$
\left(w_{t}(i), w_{t+1}(i), w_{t+2}(i)\right)=A_{t} \tilde{r}_{t}\left(1, \beta A_{t+1} r_{t+1}, \beta^{2} A_{t+1} A_{t+2} r_{t+1} \tilde{r}_{t+2}\right)
$$

if $i$ is solvent, and

$$
\left(w_{t}^{b}(i), w_{t+1}^{b}(i), w_{t+2}^{b}(i)\right)=A_{t} r_{t}^{b}\left(1, \beta A_{t+1} r_{t+1}, \beta^{2} A_{t+1} A_{t+2} r_{t+1}\right),
$$

where

$$
r_{t}^{b}=\tilde{r}_{t}+(1-m) r_{t} \theta_{t}(m)
$$

if $i$ defaults at $t$. The corresponding optimum consumption vectors in solvency and default are

$$
\left(c_{t}(i), c_{t+1}(i)\right)=(1-\beta) A_{t} \tilde{r}_{t}\left(1, \beta A_{t+1} r_{t+1}\right),
$$




$$
\left(c_{t}^{b}(i), c_{t+1}^{b}(i)\right)=(1-\beta) A_{t} r_{t}^{b}\left(1, \beta A_{t+1} r_{t+1}\right)
$$

Let $v_{t}^{s}(w), v_{t}^{b}(w)$ be the respective value functions at $t$ of a solvent borrower and a bankrupt one, conditional on available resources $w$. Both value functions are logarithmic and, for any $\lambda>0$, are easily shown to satisfy

$$
v_{t}^{j}(\lambda w)=v_{t}^{j}(w)+\frac{1}{1-\beta} \log \lambda \quad j=s, b .
$$

For one unit of initial equity at $t$, we combine Eqs. (23a), (23b) and (23c) and (24a), (24b) with the Bellman definitio of value functions:

$$
\begin{gathered}
v_{t}^{s}\left[w_{t}(i)\right]=\log \left[c_{t}(i)\right]+\beta \log \left[c_{t+1}(i)\right]+\beta^{2} v_{t+2}^{s}\left[w_{t+2}(i)\right], \\
v_{t}^{b}\left[w_{t}^{b}(i)\right]=\log \left[c_{t}^{b}(i)\right]+\beta \log \left[c_{t+1}^{b}(i)\right]+\beta^{2} v_{t+2}^{b}\left[w_{t+2}^{b}(i)\right] .
\end{gathered}
$$

Debt limits are now easy to calculate from (25), the Bellman Eqs. (26a), (26b) and the equality of payoffs for solvency and default at $t, t+2$ :

$$
v_{t}^{s}\left[w_{t}(i)\right]=v_{t}^{b}\left[w_{t}^{b}(i)\right] .
$$

Combining this equation with (25) we obtain the indifference condition

$$
v_{m}^{s}\left(\tilde{r}_{t}\right)=v_{m}^{b}\left(r_{t}^{b}\right) \text { for } m=t, t+2, \ldots
$$

Next we substitute Eqs. (23a), (23b), (23c) and (26a), (26b) into (27) to get

$$
0=(1+\beta) \log \left(\tilde{r}_{t} / r_{t}^{b}\right)+\beta^{2}\left[v_{t+2}^{s}\left(\tilde{r}_{t} \tilde{r}_{t+2}\right)-v_{t+2}^{b}\left(r_{t}^{b}\right)\right] .
$$

Repeated use of Eq. (25) leads to

$$
\begin{aligned}
& 0=(1+\beta) \log \left(\tilde{r}_{t} / r_{t}^{b}\right)+\beta^{2} {\left[\log \left(\tilde{r}_{t} / r_{t}^{b}\right) /(1-\beta)+v_{t+2}^{s}\left(\tilde{r}_{t+2}\right)\right.} \\
&\left.-v_{t+2}^{b}\left(\frac{1}{r_{t+2}^{b}} r_{t+2}^{b}\right)\right] \\
&=\left(1+\beta+\frac{\beta^{2}}{1-\beta}\right) \log \left(\tilde{r}_{t} / r_{t}^{b}\right)-\frac{\beta^{2}}{1-\beta} \log \left(\frac{1}{r_{t+2}^{b}}\right) .
\end{aligned}
$$

Lastly, we substitute the definition of $\tilde{r}_{t}$ and $r_{t}^{b}$ from Eqs. (18a) and (23c) into (28) to obtain the recursive relation

$$
\frac{1+\left(1-m r_{t}\right) \theta_{t}}{1+\left(1-r_{t}\right) \theta_{t}}=\left[1+\left(1-m r_{t+2}\right) \theta_{t+2}\right]^{\beta^{2}} \text {. }
$$

Several key intuitive results for comparative statics and dynamics follow from this equation: 
1. For fi ed values $\left(m, \theta_{t+2}\right)$, the current debt limit $\theta_{t}$ on efficien producers shrinks when the cost of capital, $r_{t}$ or $r_{t+2}$, goes up either now or in the future.

2. Debt limits are connected by a dynamic complementarity. Ceteris paribus, the current debt limit is an increasing function of the future one, which influence the continuation utility of solvency and the current default penalty.

3. Strong property rights raise debt limits and thicken financia markets. In any steady state with constant $\left(\theta_{t}, r_{t}\right), \theta$ is an increasing function of $m$.

4. The financiall autarkic equilibrium $\theta_{t}=0$ for all $t$ always solves Eq. (29) for any value of $m \in[0,1]$.

5. Credit limits will typically bind on those who benefi least from asset markets, that is, producers with relatively small marginal-product fluctuations These producers will be rationed in equilibrium and may even be denied any credit.

\subsection{Deterministic equilibrium dynamics}

Combining the loan market clearing condition (21), the default-deterring relation (29) and the consumption plans in Eqs. (20a) and (20b), we express equilibrium over time as a deterministic dynamical system in the state vector $\left(r_{t}, \theta_{t}, x_{t}\right)$ where $x_{t}=e_{t}(i) / e_{t}(j)$ is the ratio of equity owned by the efficien producer $i$ relative to that of the inefficien producer $j$. Eqs. (20a), (20b) and (21) reduce to

$$
\begin{aligned}
& x_{t} x_{t+1}=\frac{r_{t}}{1+\left(1-r_{t}\right) \theta_{t}}, \\
& \theta_{t} x_{t} \leq 1 \text { if } r_{t}=z_{t} \text {, } \\
& =1 \text { if } r_{t} \in\left(z_{t}, 1\right) \text {, } \\
& \geq 1 \text { if } r_{t}=1 \text {. }
\end{aligned}
$$

The system consists of Eqs. (29), (30a), (30b) plus an initial condition that pins down $x_{0}$. A solution sequence $\left(r_{t}, \theta_{t}, x_{t}\right)$ describes fully all variables of interest, including aggregate output

$$
Y_{t}=A_{t}\left[k_{t}(i)+z_{t} k_{t}(j)\right],
$$

where

$$
\begin{aligned}
k_{t}(i) & =e_{t}(i)+\theta_{t} e_{t}(i) & & \text { if } r_{t}=z_{t} \\
& =e_{t}(i)+e_{t}(j) & & \text { if } r_{t}>z_{t}
\end{aligned}
$$

In this economy with two types of technology all capital is employed efficientl if $r_{t}>z_{t}$ but not if $r_{t}=z_{t}$. In environments with many technologies, some capital will always be misallocated unless the yield on loans exceeds the MPK of the agent with the second highest productivity. From (31a), (31b) and $K_{t}=e_{t}(0)+e_{t}(1)$, we obtain expressions for aggregate output and capital, i.e.,

$$
Y_{t}=\frac{x_{t}\left[1+\theta_{t}\left(1-r_{t}\right)\right]+r_{t}}{1+x_{t}} A_{t} K_{t},
$$




$$
\frac{K_{t+1}}{K_{t}}=\frac{\beta A_{t}}{1+x_{t}}\left[r_{t}+\left(1+\left(1-r_{t}\right) \theta_{t}\right) x_{t}\right] .
$$

One familiar solution to Eqs. (29) and (30a), (30b) is financial autarky or zero capital mobility. When $z_{t}$ is constant, this one corresponds to the state vector

$$
\begin{aligned}
& \left(r_{t}, \theta_{t}, x_{t}\right)=\left(z, 0, x_{0}\right) \quad \text { for } t=0,2, \ldots \\
& =\left(z, 0, z / x_{0}\right) \text { for } t=1,3, \ldots
\end{aligned}
$$

and exists for all values of the property rights parameter $m \in[0,1]$. Another familiar solution, perfect capital mobility, is supported by the state vector

$$
\begin{aligned}
& \left(r_{t}, \theta_{t}, x_{t}\right)=\left(1, \theta_{t}^{*}, x_{0}\right) \quad \text { for } t=0,2, \ldots \\
& =\left(1, \theta_{t}^{*} 1 / x_{0}\right) \text { otherwise, }
\end{aligned}
$$

where $\left(\theta_{t}^{*}\right)$ is any sequence that never falls below the larger of $x_{0}$ and $1 / x_{0}$. Notice that, for $r_{t}=1$, equation (29) has no bounded solution if $m<1$, and infinitel many if $m=1$. Perfect mobility equilibrium exists in the environment if, and only if, property rights are fully enforced. Intuitively, if $R_{t}=A_{t}$ in all periods, the leverage effect vanishes, and exclusion from asset trading harms no agent.

\subsection{The output gap}

Whenever the interest rate is below the productivity of the most efficien technology, consumption plans will be inferior to perfect mobility outcomes because productive agents enjoy a higher rate of return on their wealth portfolio than do unproductive agents. The key issue that remains is inefficien production, which results from deploying capital to technologies inside the aggregate production possibilities frontier of the economy. This occurs only if $r_{t}=z_{t}$ and causes output to fall below the frontier. ${ }^{14}$

To examine this output gap we suppose $z_{t}=z<1$ for all $t$, and rewrite the dynamical system in Eqs. (29) and (30a), (30b) in the following form

$$
\begin{gathered}
\theta_{t+2}=f\left(\theta_{t} ; \beta, m, z\right) \quad t=0,1, \ldots \\
x_{t+1} x_{t}=\frac{z}{1+(1-z) \theta_{t}}, \\
\theta_{t} x_{t} \leq 1 .
\end{gathered}
$$

The map $f$ has financia autarky, $\theta=0$, as a fi ed point for any value of the parameter vector $(\beta, m, z)$.

It is easy to check from Eqs. (29) that autarky is an indeterminate steady state if $\beta^{2}>(1-m) z /(1-m z)$ and determinate otherwise. In the latter event, there

\footnotetext{
14 Equilibria of the type we are seeking are ruled out in formulations like Alvarez and Jermann (2000) which focus on high-interest-rate allocations.
} 
also exists an indeterminate state $\theta_{L}>0$ with positive but limited capital mobility. This state exists if, and only if,

$$
z>\beta^{2} \text { and } m<\left(z-\beta^{2}\right) /\left(\left(1-\beta^{2}\right) z\right)
$$

that is, if, and only if, gains from arbitrage are small, and property rights are not too strong. If (37) holds, then we can show that $z \theta_{L} \leq 1$, and the following outcomes are solutions to the dynamical system (36):

1. If (37) holds, then for any initial value of the equity distribution parameter $x_{0}$ such that

$$
z \theta_{L} /\left[1+(1-z) \theta_{L}\right] \leq x_{0} \leq 1 / \theta_{L}
$$

there is an indeterminate periodic equilibrium with limited capital mobility

$$
\begin{aligned}
& \left(r_{t}, \theta_{t}, x_{t}\right)=\left(z, \theta_{L}, x_{0}\right) \quad \text { if } t=0,2, \ldots \\
& =\left(z, \theta_{L}, \frac{z}{\left[1+(1-z) \theta_{L}\right] x_{0}}\right) \text { if } t=1,3, \ldots
\end{aligned}
$$

For each $x_{0}$ there is also a pair of initial debt-equity limits $\left(\theta_{0}, \theta_{1}\right)$ that support dynamical equilibrium sequences like the ones define in (39), except that $\theta_{t}$ converges monotonically to $\theta_{L}$.

2. If (37) holds, there is also a determinate autarkic state. If (37) fails, then all equilibrium sequences $\left(z, \theta_{t}, x_{t}\right)$ converge monotonically to the periodic autarkic state $\left(z, 0, x_{t}\right)$ where $x_{t}=x_{0}$ if $t=0,2, \ldots$, and $x_{t}=z / x_{0}$ otherwise.

3. Debt limits are generally indeterminate because they are dynamically complementary; current ones are influence by expectations of future ones. This channel vanishes when debt limits are identically zero; autarkic equilibria are unique.

4. Equilibria associated with low initial values of the debt-equity ratio are constrained inefficient, that is, dominated by others with higher initial debt limits. Any policy that lowers interest rates has a chance of improving welfare of all households. This is only a chance because lower real yields relax debt limits but also encourage the use of less productive technologies. ${ }^{15}$

All equilibria featuring a positive output gap satisfy equations (30a), (32) and (33) with $r_{t}=z_{t}$. In particular,

$$
\begin{gathered}
x_{t} x_{t+1}=\frac{z_{t}}{1+\left(1-z_{t}\right) \theta_{t}}, \\
Y_{t}=B_{t} K_{t}, \\
K_{t+1} / K_{t}=\beta B_{t},
\end{gathered}
$$

\footnotetext{
${ }^{15}$ Indeterminacy and constrained inefficien y are features of equilibrium in certain incomplete market models like Angeletos and Calvet (2006) in which a high (low) interest rate sustains itself because it discourages (favors) the accumulation of buffer stocks, which in turn discourages (favors) risk taking, leading to a low (high) stock of physical capital.
} 
and

$$
n_{t}=\frac{Y_{t+1}}{Y_{t}}=\beta B_{t+1},
$$

where

$$
B_{t}=\frac{z_{t}+\left[1+\theta_{t}\left(1-z_{t}\right)\right] x_{t}}{1+x_{t}} A_{t}<A_{t}
$$

is the modified Solow residual.

Financially autarkic states, with zero debt limits, simplify these equations to

$$
\begin{gathered}
x_{t} x_{t+1}=z_{t}, \\
B_{t}=\frac{z_{t}+x_{t}}{1+x_{t}} A_{t} .
\end{gathered}
$$

In all of these environments, the entire path of output simply reflect the history of the modifie Solow residual, just as it does in the standard DGE. In fact, if $\left(Y_{t}, Y_{t}^{*}\right)$ are, respectively, the output sequences of an economy with limited mobility, and of one with perfect mobility, then

$$
Y_{t}^{*}=\beta^{t} K_{0} \prod_{s=0}^{t} A_{s}, \quad Y_{t}=\beta^{t} K_{0} \prod_{s=0}^{t} B_{s} .
$$

What drives the similar-looking residuals A and B? In each of them, fluctu ations and growth in aggregate output are completely define by movements in factor productivity, just as they do in real business cycle theory. The only difference is that, in an economy with perfect financia markets, productivity is entirely driven by movements in the PPF whereas, under financia frictions, it is also influ enced by idiosyncratic shocks, financia market conditions, and the distribution of wealth among households.

\section{Rethinking total factor productivity}

Equation (41) lays bare the forces that drive the Solow residual in economies featuring output gaps. Equation (42b) gives a starker example for an economy completely lacking financia markets. In both these expressions, the residual does not simply describe the aggregate production possibilities frontier; it reveals exactly how far inside the PPF current output lies. Fluctuations in this output gap are caused by financia market imperfections that limit arbitrage among households and firms When these limitations bind, resources are misallocated in favor of low productivity technologies and low-marginal-utility consumers.

Equation (41) also suggests that when interest rates rise, factor productivity improves when debt limits do, and also when the distribution of equity temporarily favors efficien producers. All these events redirect capital toward more productive users. The same equation reveals that productivity fluctuates within the production possibility frontier in response to movements in the distribution of 
wealth. To see this, we examine the dynamics of financia autarky. In particular, assume $z_{t}=z \in(0,1)$ for all $t$, and defin the resource utilization factor $\phi_{t}=B_{t} / A_{t} \in[z, 1]$. Then equations (42a), (42b) reduce to the one-dimensional dynamical system

$$
\phi_{t+1} \phi_{t}=z
$$

with an initial condition $\phi_{0}=\left(z+x_{0}\right) /\left(1+x_{0}\right)$ pinned down by Eq. (42b). The unique solution

$$
\begin{aligned}
B_{t} & =\frac{z+x_{0}}{1+x_{0}} A_{t} & \text { if } t=0,2, \ldots \\
& =\frac{z\left(1+x_{0}\right)}{z+x_{0}} A_{t} & \text { if } t=1,3, \ldots
\end{aligned}
$$

shows that endogenous changes in the distribution of wealth convert a one-time impulse from the production possibility frontier into a long-lasting response in output growth. The same solution hints that impulse responses may amplify technology shocks. In particular, if the initial distribution of wealth is unfavorable to the efficien producer, that is, if

$$
x_{0}<\sqrt{z},
$$

then the modifie Solow residual may oscillate more than the production possibilities frontier. Growth rate fluctuation have amplitude

$$
n_{t}^{*} / n_{t-1}^{*}=A_{t+1} / A_{t}
$$

if capital mobility is perfect. Suppose now that $A_{t}$ is small at $t=0,2, \ldots$, and large at $t=1,3, \ldots$. Then ratios of autarkic growth rates are

$$
\begin{aligned}
n_{t} / n_{t-1} & =\frac{z\left(1+x_{0}\right)^{2}}{\left(z+x_{0}\right)^{2}} \frac{A_{t+1}}{A_{t}} \quad \text { if } t=0,2, \ldots \\
& =\frac{\left(z+x_{0}\right)^{2}}{z\left(1+x_{0}\right)^{2}} \frac{A_{t+1}}{A_{t}} \quad \text { if } t=1,3, \ldots
\end{aligned}
$$

As $x_{0} \rightarrow 0$, autarky amplifie technology booms by a factor of $1 / z$ for $t=0,2, \ldots$ and worsens technology busts by the same factor.

Another amplificatio channel opens if movements in the aggregate PPF happen to be in the same direction as relative productivity changes within the frontier, that is, if inefficien producers have larger than average productivity gains in expansions and larger than average productivity declines in contractions. This requires relative productivity $z_{t}$ to be an increasing function of the deviation of the technology frontier $A_{t}$ from its trend. ${ }^{16}$ In that case, relative productivity changes amplify downward or upward impulses from the PPF.

\footnotetext{
16 Storesletten et al. (2004)fin evidence of countercyclical dispersion in labor incomes and consumption; Eisfeldt and Rampini (2006) fin countercyclical dispersion of productivity among firms In addition, Campbell et al. (2001) give evidence of countercyclical dispersion for individual and market asset returns.
} 


\section{Rethinking the stochastic discount factor}

Among the enduring features of equity returns (Campbell 2003) are their large average value relative to Treasury Bill yields and their volatility relative to the growth rate of dividends. Aggregate dividends in developed nations do not contain enough undiversifiabl risk to justify the equity premiums we observe in the last hundred years. Both of these puzzles seem to require a convincing definitio for the stochastic discount factor (SDF) or pricing kernel used to discount future payoffs back to the present. If $m_{t, s}$ is the market value at $t$ of one consumption unit at $t+s$, then the price $P_{t}$ of an asset, with dividend stream $\left(d_{t+s}\right)_{s=1}^{\infty}$ is the expected discounted value of all future dividends conditional on all information available at $t$, that is,

$$
P_{t}=E_{t}\left\{\sum_{s=1}^{\infty} m_{t, s} d_{t+s}\right\} .
$$

How does the market discount future dividends? In an exchange economy with perfect asset markets and identically homothetic utility functions $u(c)=c^{1-\gamma} / 1-\gamma, \gamma \geq 0$, the SDF is the familiar expression for the marginal rate of substitution of a hypothetical stand-alone household that owns the entire fl w of consumption or income, that is,

$$
m_{t, s}=\beta^{s}\left(c_{t} / c_{t+s}\right)^{\gamma}
$$

Since aggregate consumption growth is too stable to permit much volatility in asset prices or explain excess equity returns, the literature has moved away from perfect markets. Economies with incomplete market participation (Mankiw and Zeldes 1991; Constantinides et al. 2002) or with uninsurable idiosyncratic risks (Constantinides and Duffi 1996; Storesletten et al. 2004) are examples of environments in which the SDF reflect the consumption growth of currently unconstrained participants in asset markets.

If $s_{t} \in[0,1]$ is the aggregate consumption share at time $t$ of unconstrained participants in financia markets, and $f_{t+s}$ is the consumption share of the same group at $t+s$, then the stochastic discount factor in equation (48a),

$$
\hat{m}_{t, s}=\beta^{s}\left(c_{t} / c_{t+s}\right)^{\gamma}\left(s_{t} / f_{t+s}\right)^{\gamma},
$$

depends on the consumption growth rate of households unconstrained at $t$. More precisely, the last term on the right-hand side of Eq. (48b) corrects the standard stochastic discount factor by the growth in the share of consumption that accrues to those who do not face binding short-sales constraints when they trade claims on consumption in current history $H_{t}$ against consumption in some future history $H_{t+s}$.

Who are these people and what is their consumption growth? The question is of interest because it tries to identify the characteristics of key traders in financia markets. These markets have been dominated for a long time by mutual funds and by direct investment from self-employed persons and other wealthy individuals with substantial variability in personal incomes. It is conceivable that both membership 
and aggregate income fluctuat substantially for this group of active investors, and that their consumption plans are riskier than those of the economy at large. ${ }^{17}$

In theory the pricing kernel depends critically on the structure of financia markets. A financia autarky environment, with all asset markets closed, identifie the discount factor in each possible history by the lowest income growth rate among all agents consuming at time $t$. On the other hand, if idiosyncratic risks are uninsurable but securities can be traded across aggregate states, as in the work of Constantinides and Duffi (1996), then current consumption plans will generally depend on the entire history of events, that is, on individual buffer stocks built to insure their owners against idiosyncratic income fluctuations

This inherent non-stationarity of individual consumption complicates enormously the job of calculating a proper pricing kernel for economies with uninsurable risks because the consumption-Euler equations for traded assets apply to each individual consumption sequence but fail for average or aggregate consumption. To price aggregate risks, one needs to solve the informationally and computationally daunting problem of constructing a wealth-weighted "average" SDF from individual ones and from an extremely complex distribution of wealth.

Endogenous debt limits ease the job of computing a market discount factor because they permit all financia markets to stay open all the time, and preserve stationarity in consumption decisions and in the distribution of wealth. Asset returns are the outcome of actions by agents with slack debt constraints, that is, by those who have the most to gain from short positions in asset markets. In these environments, it is important to understand that every agent will have to deal with binding debt limits in some history of events.

To see why, imagine consumption plans in a deterministic economy consisting of agents with different income profiles and a common logarithmic utility function. The perfect mobility equilibrium is supported by an interest rate equal to the sum of the rate of time preference and the growth rate of aggregate income. With limited capital mobility, however, agents with very low gains from trade, that is, with almost constant shares of aggregate income, will be kept out of the asset market due to zero debt limits. That is the only way to keep them from defaulting; it implies an equilibrium interest rate below the sum of the time preference and aggregate consumption growth rates. It also means that consumption by agents who are never rationed will keep falling, when expressed as a share of aggregate consumption, until it drops uniformly below their endowment sequence. At that point, unconstrained households will default on all loans, and the presumed equilibrium without binding constraints will unravel. ${ }^{18}$

Here is a simple way to understand how the SDF is determined in economies with limited mobility, taken from Azariadis and Kaas (2007). Consider a deterministic economy with two infinitely-l ved persons $i=1,2$ facing self-canceling variations in individual incomes. Endowment vectors are

$$
\begin{aligned}
\left(w_{t}^{1}, w_{t}^{2}\right)=(\alpha, 1-\alpha) & \text { if } t=0,2, \ldots \\
& =(1-\alpha, \alpha) \quad \text { if } t=1,3, \ldots
\end{aligned}
$$

\footnotetext{
${ }^{17}$ For example, the growth rate of aggregate dividends has about fi e times the standard deviation of the aggregate consumption growth rate.

18 This argument is based on joint work in progress with Jim Bullard.
} 
where $\alpha \in[1 / 2,1]$. At a price $p_{t}$, agents can trade a unit stock of non-depreciating capital (Lucas "tree") which pays a constant dividend $d \geq 0$ each period. Total income is $y=1+d$ every period. Finally, agent 1 is uniformly more patient than agent 2 , that is,

$$
V_{1}=\sum_{t=0}^{\infty} \beta^{t} \log c_{t}^{1}, \quad V_{2}=\sum_{t=0}^{\infty} \gamma^{t} \log c_{t}^{2} \quad 0<\gamma<\beta<1 .
$$

A perfect financia market will permit the impatient agent to achieve high initial consumption, which converges asymptotically to zero, by selling off initial assets to, and borrowing against future income from, the patient agent. Asymptotic values for consumption, asset prices and asset returns are

$$
\left(c_{t}^{1}, c_{t}^{2}, p_{t}, R_{t}\right) \rightarrow\left(0,1+d, \frac{\beta}{1-\beta} d, \frac{1}{\beta}\right)
$$

The entire equilibrium vector converges monotonically to its asymptotic value as the market comes gradually to be dominated by the patient household: $\left(R_{t}, c_{t}^{1}\right)$ drop as $\left(p_{t}, c_{t}^{2}\right)$ rise.

Can an auctioneer, empowered to exclude defaulters from the asset market in perpetuity, invent debt constraints to implement the allocation $\left(c_{t}^{1}, c_{t}^{2}\right)$ implied by Eq. (49)? The answer is clearly not, unless $\alpha=1$. No debt constraint can deter the impatient agent from defaulting once his consumption falls permanently below income. Debt limits will surely bind in this economy.

A particularly interesting equilibrium with zero debt limits is one in which households trade the entire tree, buying it when income is $\alpha$, selling it when income is $1-\alpha$. The asset market reflect the taste and income of unconstrained tree sellers, satisfying the consumption-Euler equations

$$
\begin{aligned}
\frac{\alpha-p_{t+1}}{1-\alpha+p_{t}}<\frac{1-\alpha+p_{t+1}}{\alpha-p_{t}} & =\gamma R_{t} \quad \text { if } t=0,2, \ldots \\
& =\beta R_{t} \quad \text { if } t=1,3, \ldots
\end{aligned}
$$

where the asset return $R_{t}$ is define from the no arbitrage condition

$$
R_{t}=\left(p_{t+1}+d\right) / p_{t} .
$$

Solutions to these relations must satisfy

$$
\begin{aligned}
p_{t+1} & =\frac{(1-\alpha+\gamma d) p_{t}-\alpha \gamma d}{\alpha \gamma-(1+\gamma) p_{t}} \quad \text { if } t=0,2, \ldots \\
& =\frac{(1-\alpha+\beta d) p_{t}-\alpha \beta d}{\alpha \beta-(1+\beta) p_{t}} \quad \text { if } t=1,3, \ldots
\end{aligned}
$$

plus the inequality

$$
2 \alpha-1<p_{t} p_{t+1}, \quad \text { all } t
$$

A unique periodic solution exists if the tree is not sufficientl productive to overcome individual income fluctuation when it changes hands. Intuitively, the asset price $p_{0}$ in even periods will be lower than the odd-period price $p_{1}$ because the unconstrained agent at $t=0,2, \ldots$ is less patient, and discounts future dividends more heavily, than his odd-period counterpart. Changes in market participation induce discount factor shifts that move asset returns even if dividends remain constant. 


\section{Conclusions}

A big part of Edward Prescott's intellectual contribution to dynamic general equilibrium and to modern macroeconomics can be summed up in two terms: the Solow residual and the stochastic discount factor. For it was he who, along with Finn Kydland, convinced the profession about the overwhelming importance of factor productivity as the engine of both aggregate fluctuation and economic growth, by appropriately calibrating examples of a stochastic optimum growth model. It was also he, along with Rajnish Mehra, who insisted that long-run stock returns are intimately connected with the stochastic discount factor of a similar neoclassical growth model.

This essay began with the guess that the Solow residual and the stochastic discount factor retain considerable descriptive power outside strictly classical environments satisfying the two fundamental theorems of welfare economics. We went on to assert that both of these concepts will remain essential to any future DGE theory that seeks to explain jointly and simultaneously every key observation from growth, business cycles and asset markets.

That assertion was put to the test in a variety of examples where restrictions on the property rights of lenders, of the type proposed by Eaton and Gersovitz (1981), Bulow and Rogoff (1989) and Kehoe and Levine (1993), diminish arbitrage and limit capital mobility between producers and consumers. These examples reinforce Prescott's message that the Solow residual controls output fluctuation and growth, and that an appropriately define stochastic discount factor can explain returns on diversifie asset portfolios. All we need to do is develop more sophisticated theories for these two concepts. ${ }^{19}$

For example, current estimates of total factor productivity convey information not just about the aggregate technology frontier but also about how far inside that frontier the economy operates at each point in time. That position appears to depend on additional technology variables like relative or sectoral productivities $;{ }^{20}$ on financia variables like debt-equity ratios, interest rates, and the distribution of equity positions; and on institutional variables like the property rights of lenders. When modifie in this way, factor productivity movements are consistent with a zero output gap as well as a positive one; with large business cycles as well as with small ones; with inefficien equilibria as well as with efficien ones; with indeterminate outcomes as well as unique ones. They are also consistent with fast, predictable growth and active financia markets in societies with strong property rights; and with slower, unpredictable growth and lethargic financia markets in societies with weak property rights.

The interaction of financia variables with the wealth distribution seems key to the modifie Solow residual. Idiosyncratic productivity shocks defin how badly the economy needs to reallocate its capital; debt limits and other financia variables spell out how much reallocation is permitted under the existing distribution of equity positions, and what the future distribution will be. This channel controls

\footnotetext{
19 This is also suggested by Prescott (1998).

${ }^{20}$ Redeployed capital averages about $25 \%$ of all capital expenditure. Davis et al. (1996) provide a rich source of data on how jobs at the plant level are redeployed in response to sectoral or idiosyncratic productivity shocks. Eisfeldt and Rampini (2006) summarize Compustat data on capital reallocation by $\mathrm{f} r \mathrm{rs}$.
} 
both the distance of factor productivity from the technology frontier and how much actual productivity will oscillate within that frontier. In financia autarky, the most egregious case of capital immobility, the productivity residual fluctuates endogenously, even if the technology frontier is stationary, in response to periodic shifts in relative factor productivities.

Amendments are also needed to the stochastic discount factor which must aim to connect discounting with individual decisions to participate in, or stay out of, financia markets; and to aggregate the characteristics of unconstrained traders in these markets into observable features of the income or wealth distribution. Changes in aggregated individual characteristics will add to the pricing kernel an endogenous element of time variation which recent theoretical work (Lustig 2003) and empirical research (Lettau and Ludvigson 2001) have found to be essential in constructing useful testable hypotheses about asset returns.

\section{References}

Aghion, P., Howitt, P: A model of growth through creative destruction. Econometrica 60, 323-351 (1992)

Aiyagari, R.: Uninsurable idiosyncratic risk and aggregate saving. Q J Econ 109, 659-684 (1994)

Alvarez, F., Jermann, U.: Eff ciency, equilibrium and asset picing with risk of default. Econometrica 68, 775-797 (2000)

Angeletos, M., Calvet, L.: Idiosyncratic production risk, growth and the business cycle. J Monet Econ 53, 1095-1116 (2006)

Antunes, A., Cavalcanti, T., Villamil, A.: The effect of financia repression and enforcement on entrepreneurship and economic development. University of Illinois, Working Paper (2006)

Azariadis, C.: The theory of poverty traps: What have we learned? In: Poverty Traps, Chap 2 Bowles, S., Durlauf, S., Hoff, K. (eds.) Princeton: Princeton University Press (2005)

Azariadis, C., Bullard, J., Ohanian, L.: Trend-reverting f uctuations in the life-cycle model. J Econ Theory 119, 334-356 (2004)

Azariadis, C., Kaas, L.: Endogenous financia development, growth and volatility. University of Konstanz Working Paper (2004)

Azariadis, C., Kaas, L.: Asset price f uctuations without aggregate shocks. Forthcoming in J Econ Theory (2007)

Azariadis, C., Kaas, L.: Credit and growth under limited commitment. Forthcoming in Macroecon Dynam (2005)

Benhabib, J., Farmer, R.: Indeterminacy and increasing returns J Econ Theory 63, $19-41$ (1994)

Bewley, T.: Dynamic implications of the form of the budget constraint. In: Sonnenschein, H., (ed.) Models of Dynamic Economies Springer, Berlin Heidelberg New York (1986)

Blanchard, O., Simon, J.: The long and large decline in US output volatility. Brook Pap Econ Activ, 1, 135-164 (2001)

Breeden, D.: An intertemporal asset pricing model with stochastic consumption and investment opportunities. J Financ Econ 7, 265-296 (1979)

Brock, W., Mirman, L.: Optimal economic growth and uncertainty: the discounted case. J Econ Theory 4, 479-513 (1972)

Bullard, J.: Learning equilibria. J Econ Theory 64, 468-485 (1994)

Bulow, J., Rogoff K.: Sovereign debt: is to forgive to forget?. Am Econ Rev 79, 43-50 (1989)

Calvo, G.: Staggered prices in a utility maximizing framework. J Monet Econ 12, 383-398 (1983)

Campbell, J.: Consumption-based asset pricing. In: Constantinides, G., Harris, M., Stulz, R. (eds.) Handbook of the Economics of Finance. Elsevier B.V Amsterdam (2003)

Campbell, J., Lettau, M., Malkiel, B., Xu, Y.: Have individual stocks become more volatile? J Fin 56, 1-43 (2001)

Cass, D.: Optimum growth in an aggregative model of capital accumulation. Rev Econ Stud 32, 223-240 (1965) 
Christiano, L., Eichenbaum, M., Evans, C.: Monetary policy shocks: what have we learned and to what end? In: Taylor, J., Woodford, M. (eds.) Handbook of Monetary Economics, Chap 2. Amsterdam: North-Holland (1999)

Cogley, T., Nason, J.: Output dynamics in real business cycle models. Am Econ Rev 85, 492-511 (1995)

Comin, D., Mulani, S.: Diverging trends in macro and micro volatility: facts. NYU Working Paper (2004)

Constantinides, G., Donaldson, J., Mehra, R.: Junior can't borrow: a new perspective on the equity premium puzzle. Q J Econ 118, 269-296 (2002)

Constantinides, G., Duffie D.: Asset pricing with heterogeneous consumers. J Polit Econ 104, 219-240 (1996)

Davis, S., Haltiwanger, J., Schuh, S.: Job Creation and Destruction, Cambridge: MIT Press (1996)

Diaz-Jimenez, J., Quadrini, V., Rodriguez, S., Rios-Rull, V.: Updated facts on the US distribution of earnings, income and wealth. Q. Rev. Federal Reserve Bank Minneapolis 26, 2-35 (2002)

Eaton, J., Gersovitz, M.: Debt with potential repudiation: theoretical and empirical analysis. Rev Econ Stud 48, 289-309 (1981)

Eisfeldt, A., Rampini A.: Capital reallocation and liquidity. J Monet Econ 53, 369-399 (2006)

Evans, G., Honkapohja, S.: Learning and Expectations in Macroeconomics. Princeton: Princeton University Press (2001)

Gali, J.: New perspectives on monetary policy, inflation and the business cycle. In: Advances in Economics and Econometrics, Vol. 3. Dewatripont, M., Hansen, L., Turnovsky, S. Cambridge: Cambridge University Press (2003)

Grossman, G., Helpman, E.: Quality ladders and product cycles. Q J Econ 106, 557-589 (1991)

Hayek, F.: Prices and Production. London: Routledge \& Kegan Paul (1932) Investment Company Institute, Profil of Mutual Fund Shareholders, Washington, D.C (2004)

Jeong, H., Townsend, R.: Sources of TFP: occupational choice and $\mathrm{f}$ nancial deepening. University of Chicago Working Paper (2005)

Kehoe, T., Levine D.: Debt-constrained asset markets. Rev Econ Stud 60, 865-888 (1993)

Kehoe, T., Levine D.: Liquidity-constrained versus debt-constrained asset markets. Econometrica 69, 575-598 (2001)

King, R., Rebelo, S.: Resuscitating real business cycles. Handbook of Monetary Economics, Chap. 14. op.cit (1999)

Kiyotaki, N., Moore, J.: Credit cycles. J Polit Econ 105, 211-248 (1997)

Klenow, P., Rodriguez-Clare, A.: Economic growth: a review essay. J Monet Econ 40, 597-617 (1997)

Koopmans, T.: On the concept of optimal growth. In: The Econometric Approach to Development Planning, pp. 225-287. Chicago: Rand McNally (1965)

Krusell, P., Smith, A.: Income and wealth heterogeneity in the macroeconomy. J Politi Econ 106, 867-896 (1998)

Kydland, F., Prescott, E.: Time to build and aggregate f uctuations. Econometrica 50, 1345-1371 (1982)

Lettau, M., Ludvigson, S.: Consumption, aggregate wealth and expected stock returns. J Fin 56, 815-849 (2001)

Lucas, R.: Expectations and the neutrality of money. J Econ Theory 4, 103-124 (1972)

Lucas, R.: Asset prices in an exchange economy. Economertica 46, 1429-1445 (1978)

Lucas, R., Stokey, N.: Optimal fisca and monetary policy in an economy without capital. J Monet Econ 12, 55-93 (1983)

Lustig, H.: The aggregate price of risk and the wealth distribution. UCLA Working Paper (2003)

Mankiw, G., Zeldes, S.: The consumption of stockholders and non-stockholders. J Fin Econ 29, 97-112 (1991)

McGrattan, E., Prescott, E.: Average debt and equity returns: puzzling? Am Econ Rev 94, 392397 (2003)

McGrattan, E., Prescott, E.: Taxes, regulation, and the value of US and UK corporations. Rev Econ Stud 72, 767-796 (2005)

Mehra, R., Prescott E.: The equity premium: a puzzle. J Monet Econ 15, 145-161 (1985)

Mehra, R., Prescott E.: The equity risk premium: a solution? J Monet Econ 22, 133-136 (1988)

Persson, T., Tabellini, G.: Political Economics, MIT Press (2000)

Prescott, E.: Needed: A theory of total factor productivity. Int Econ Rev 39, 525-552 (1998) 
Ramey, G., Ramey, V.: Cross-country evidence on the link between volatility and growth. Am Econ Rev 85, 1138-1151 (1995)

Rotemberg, J.: Monopolistic price adjustment and aggregate output. Rev Econ Stud 49, 517-31 (1982)

Solow, R.: A contribution to the theory of economic growth. Q J Econ 70, 65-94 (1956)

Stock, J., Watson, M.: Business cycle f uctuations in US macroeconomic time series. Chap 1. In: Handbook of Monetary Economics, op.cit (1999)

Storesletten, K., Telmer, C., Yaron, A.: Cyclical dynamics with idiosyncratic labor market risk. J Polit Econ 112, 695-717 (2004)

Susskind, L.: The Cosmic Landscape: String theory and the Illusion of Intelligent Design. Boston: Little Brown (2005)

Woodford, M.: Interest and Prices. Princeton: Princeton University Press (2003) 